Creative Commons User License: CC BY-NC-ND

Abstracted by: EBSCOhost, Electronic Journals Service (EJS),

Google Scholar, Journal Seek, Scientific Commons,

Food and Agricultural Organization (FAO), CABI and Scopus

http://eoi.citefactor.org/10.11226/v23i4
Journal of Agricultural Extension

Vol. 24 (1) January, 2020

ISSN(e): 24086851; ISSN(Print); $1119944 X$

http://journal.aesonnigeria.org

http://www.ajol.info/index.php/jae

Email: editorinchief@aesonnigeria.org

\title{
Involvement of Rural Households in Oil Palm (Elaeis guineensis) Fruits Postharvest Activities in Ondo State, Nigeria
}

https://dx.doi.org/10.4314/jae.v24i1.5

\author{
Alabi, Dorcas Lola \\ Department of Agricultural Extension and Rural Development, Faculty of Agriculture, \\ Obafemi Awolowo University, Ile-Ife. Nigeria. \\ alabidorcas@yahoo.com +2348062915547
}

\section{Famakinwa, Michael}

Department of Agricultural Extension and Rural Development, Faculty of Agriculture, Obafemi Awolowo University, Ile-Ife. Nigeria.

famakinwamichael2013@gmail.com +2347039530266

\section{Akinnawonu, Oluwakemi Esther}

Department of Agricultural Extension and Rural Development, Faculty of Agriculture, Obafemi Awolowo University, Ile-Ife. Nigeria.

kemisolaesther9@gmail.com +234816529546

\section{Abstract}

The study assessed the involvement of rural households in oil palm fruits postharvest activities (PHAs) in Ondo State, Nigeria. Specifically, examined their perception towards involvement in oil palm fruits PHAs; identified oil palm fruit PHAs respondents were involved in; determined their level of involvement in those activities and identified constraints associated with their involvement. A multi-stage sampling procedure was used to select 120 processors from selected 3 LGAs in Ondo State. Data were collected using structured interview schedule and summarized with percentages, means and standard deviations while correlation and chi-square analyses were used to draw inference on hypothesis. Results showed that the majority (63.3\%) of the respondents had favourable perception towards involvement in oil palm fruits PHAs. The majority of the processors were mostly involved in marketing of palm oil (86.8\%), storage of palm oil (80\%) and packing of palm oil (60.8\%). Also, more than half (61.7\%) of the respondents had moderate level of involvement in oil palm fruit PHAs. Lack of modern processing unit ( $\bar{x}=2.96)$, inadequate access to credit facilities ( $\bar{x}=2.90)$, lack of adequate technology $(\bar{x}=2.81)$ were the major constraints limiting respondents' involvement in oil palm fruit PHAs. The result of correlation analysis showed that years of residence $(r=-0.184)$, family size $(r=0.200)$ and years of education ( $r=0.322)$ had significant relationship with respondents' involvement in oil palm fruits PHAs. The study concluded that respondents had moderate involvement in oil palm fruits PHAs and recommended that the government at the grassroot should assist in providing modern processing and functional credit facilities. 
Creative Commons User License: CC BY-NC-ND

Abstracted by: EBSCOhost, Electronic Journals Service (EJS),

Google Scholar, Journal Seek, Scientific Commons,

Food and Agricultural Organization (FAO), CABI and Scopus

http://eoi.citefactor.org/10.11226/v23i4
Journal of Agricultural Extension

Vol. 24 (1) January, 2020

ISSN(e): 24086851; ISSN(Print); $1119944 X$

http://journal.aesonnigeria.org

http://www.ajol.info/index.php/jae

Email: editorinchief@aesonnigeria.org

Keywords: Oil palm fruits, Postharvest activities, Involvement, Rural households

\section{Introduction}

Oil palm (Elaeis guineensis) is one of the most important economic tree crops in Nigeria. The global growing demand for palm oil is making oil palm cultivation becoming a means of livelihood for many rural families, and indeed the farming culture of millions of people in Nigeria. The oil palm tree is a useful crop that is relevant in all aspects of live with socioeconomic and socio-cultural values. According to lbitoye, Akinsorotan, Meludu and lbitoye (2011), oil palm is a versatile tree crop with almost all parts having economic value and useful for everyday livelihood. The different parts of oil palm include: the fronds, leaves, trunk and roots. These parts give a wide range of products which are of benefit to mankind. The importance of oil palm to the national economy of Nigeria cannot be over emphasized. It ranges from production of food for human consumption, employment, income to farmers and nation and raw materials for industries. Oil palm has been a major source of foreign exchange to Nigeria as well as source of revenue to major segment of the rural population of South East Nigeria (Onoh and Peter-Onoh, 2012). The most important product of oil palm is the palm fruit, which is processed to obtain three commercial products namely: palm oil, palm kernel oil and palm kernel cake. Palm oil and palm kernel oil are two distinct oils which are important in World Trade, (Barcelos et al., 2015). Hence, oil palm is often referred to as a crop of multiple values, which underscores its economic importance (Akangbe et al., 2011). It has been established in literature that the domestic consumption of palm oil in Nigeria, in 2017/2018, amounted to about 1.29 million metric tons (Conway, 2018). Palm oil is used in the manufacturing of margarine, soap candle, base for lipstick, waxes and polish bases in a condense form, confectionary (Embrandiri et al., 2011).

Nigeria used to be one of the world largest producers and exporters of palm oil in the early 1900 s to the 1960 s, accounting for more than $40 \%$ of global output and $82 \%$ of its export earnings. By the end of the twentieth century, the Nigerian palm oil harvest had dwindled to about $7 \%$ of the global production due to the discovery of crude oil in commercial quantity, over-reliance on traditional production methods and inefficient oil extraction practices among others (Onwumwere, Onwusiribe and Iheanatu, 2014). Although oil palm is grown in 24 states of Nigeria namely; Abia, Akwa lbom, Cross River, Rivers, Bayelsa, Imo, Anambra, Ebonyi, Enugu, Delta, Edo, Ondo, Ogun, Osun, Oyo, Ekiti, Benue, Kwara, Kogi, Nasarawa, Plateau, Taraba, Adamawa and Kaduna (especially in the southern part) (Ekenta et al. (2017), Delta, Edo, Akwa-lbom, Cross River, Bayelsa, Rivers, Anambra, Enugu, Imo, Abia, Ogun, Ondo, Oyo and Ekiti are the major palm oil producing states in Nigeria with about $80 \%$ of their total production coming from smallholders who harvest semi-wild plants (Business Innovation Growth (BIG), 2017). Palm oil is primarily gotten from three sources namely: the collection of fresh palm fruit bunches from wild groves, private plantations owned or managed by individual farmers, and large corporate or government owned plantations (Partnership Initiatives in The Niger Delta (PIND) Foundation, 2019). Several million smallholders 
Creative Commons User License: CC BY-NC-ND

Abstracted by: EBSCOhost, Electronic Journals Service (EJS),

Google Scholar, Journal Seek, Scientific Commons,

Food and Agricultural Organization (FAO), CABI and Scopus
Journal of Agricultural Extension

Vol. 24 (1) January, 2020

ISSN(e): 24086851; ISSN(Print); 1119944X

http://journal.aesonnigeria.org

http://www.ajol.info/index.php/jae

Email: editorinchief@aesonnigeria.org

are spread over an estimated area ranging from 1.65 million hectares to 2.4 million hectares and to a maximum of 3 million hectares. The estimate for oil palm plantations in Nigeria ranges from 169,000 hectares $(72,000$ ha of estate plantations and 97,000 ha of smallholder plantations) to 360,000 hectares of plantations (Agriculture Nigeria, 2019).

Oil palm fruit processing involves harvesting, threshing or bunch quartering, fruit loosening, boiling, digestion, pressing/oil extraction, clarification and packaging/storage. All these stages are done manually except the digestion or pounding of cooked fruits which is done by a diesel engine powered digester equipment (Osei-Amponsah et al., 2018). Small- scale production involves the use of traditional or semi-mechanized methods for oil extraction from the fresh fruit bunch (Adeniyi, Ogunsola and Olawusi, 2014). In addition, during processing, outdated equipment is mostly used. This method of oil palm processing is arduous, time consuming and oil yield is usually low. Often, about $25 \%-75 \%$ of potential palm oil is lost during processing (Nyakuma, 2015) while $71.8-90.6 \%$ and $9.0-28.0 \%$ palm oil end up as waste under smallholder palm oil processing in Nigeria depending on the variety of the oil palm (Ohimain, Izah, and Obieze, 2013).

Nigeria oil palm processors are classified into mechanized, semi-mechanized and smallholder categories based on the level of processing. Basically, the sector is dominated by smallholder processors accounting for over $80 \%$ of Nigeria oil palm industry and using rudimentary equipment for processing (Ohimain, Emeti and Izah, 2014; Ohimain and Izah, 2014a; Ohimain, Daokoru-Olukole, Izah and Alaka,2012; Ohimain, Oyedeji and Izah, 2012; Ohimain and Izah, 2014b). Similarly, the semimechanized palm oil processors account for about $16 \%$ while the rest $4 \%$ are mechanized processors (Ohimain and Izah, 2013; Izah, Ohimain and Angaye, 2016; Ohimain and Izah, 2014b). Generally, smallholder palm oil mills are found in several communities in Ondo State of Nigeria with few semi-mechanized and mechanized palm oil mills.

The industry is a source of livelihood to a large proportion of households in the rural areas of Ondo State, Nigeria. The employment opportunities in oil palm processing are numerous ranging from nursery of the oil palm seedling, plantation farming, palm oil mills and marketing of the final product i.e. palm oil. Ohimain, et al. (2012) reported that smallholder palm oil processing employs 3 - 12 workers (mean $=8$ ) depending on the quantity of fresh fruit bunch available for processing. Similarly, Ohimain, et al. (2012) also reported that semi mechanized processing has employment capacity of about 11 persons. However, the involvements of rural households in oil palm postharvest activities have not been adequately documented, hence, this study.

The main objective of the study was to assess the involvement of rural households in oil palm fruits PHAs in Ondo State, Nigeria. The specific objectives were to;

1. examine respondents' perception towards involvement in oil palm fruits PHAs;

2. identify level of involvement in the various oil palm fruits PHAs ; and

3. identify the constraints limiting the respondents' involvement in oil palm fruits PHAs. 
Creative Commons User License: CC BY-NC-ND

Abstracted by: EBSCOhost, Electronic Journals Service (EJS),

Google Scholar, Journal Seek, Scientific Commons,

Food and Agricultural Organization (FAO), CABI and Scopus

http://eoi.citefactor.org/10.11226/v23i4
Journal of Agricultural Extension

Vol. 24 (1) January, 2020

ISSN(e): 24086851; ISSN(Print); 1119944X

http://journal.aesonnigeria.org

http://www.ajol.info/index.php/jae

Email: editorinchief@aesonnigeria.org

\section{Methodology}

The study was carried out between March and August 2017 in Ondo State, Nigeria. The state is located on latitude $7^{\circ} 6^{\prime} 0.0180^{\prime \prime} \mathrm{N}$ and longitude $4^{\circ} 50^{\prime} 30.0984^{\prime \prime} \mathrm{E}$. A multistage sampling procedure was used to select respondents. At the first stage, three out of the eighteen Local Government Areas (LGAs) in the State were randomly selected namely; Ifedore, Okitipupa and lle Oluji. At the second stage, proportionate random technique was used to select three, three and two communities, respectively from Ifedore, Okitipupa and Ile Oluji LGAs, making a total of eight communities. These are: Owena, Igbara-oke and Ilara from Ifedore LGA; Okitipupa, Ode-aye and Irele from the Okitipupa LGA; and Onipanu and Ile Oluji from Ile Oluji LGA. At the last stage, 15 rural household members involved in oil palm fruits PHAs were randomly selected from each of the selected communities making a total of 120 respondents selected for the study. Pre-tested and validated structured interview schedule was used to collect relevant quantitative data on respondents' perception towards involvement in oil palm fruits PHAs, the various oil palm fruits PHAs they were involved in and the constraints limiting their involvement. Data collected were summarized with percentages, means and standard deviations while correlation and chisquare analyses were used to draw inference on hypothesis at 0.01 and 0.05 levels of significance.

The dependent variable for this study was involvement of respondents in oil palm fruits PHAs which was operationalized by using three indicators namely: form of involvement, nature of involvement and frequency of involvement. Respondents scores from these indicators were summed up to obtain the involvement score. The nature of involvement was measured by asking the respondents to indicate their nature of involvement which was categorized into full time (2 points) and part time (1 point). Form of involvement was measured by asking the respondents to indicate their form of involvement in oil palm fruits PHAs whether as employed labour (1 point), self-employed (2 points) and employer of labour (3 points). Frequency of involvement was determined by asking the respondents to indicate how often they were involved in oil palm fruits PHAs in a four-point Likert-type scale of very often (3), often (2), occasionally (1), and not at all (0). Respondents' involvement was categorized into low, moderate and high-level using mean, plus or minus standard deviation

\section{Results and Discussion}

\section{Perception of Respondents towards Involvement in Oil Palm Fruits PHAs}

Table 2 shows that respondents positively perceived the statements that oil palm fruit PHAs serve as means of generating income ( $\bar{x}=3.51)$, self-employment opportunity ( $\bar{x}=3.45$ ), provide a lot of raw materials for industries $(\bar{x}=3.27)$, contribute to community development $(\bar{x}=3.17)$ and that adequate oil palm fruits PHAs increase foreign exchange potentials of the oil $(\bar{x}=3.14)$. On the other hand, respondents disagreed to the negative 
Creative Commons User License: CC BY-NC-ND

Abstracted by: EBSCOhost, Electronic Journals Service (EJS),

Google Scholar, Journal Seek, Scientific Commons,

Food and Agricultural Organization (FAO), CABI and Scopus

http://eoi.citefactor.org/10.11226/v23i4
Journal of Agricultural Extension

Vol. 24 (1) January, 2020

ISSN(e): 24086851; ISSN(Print); 1119944X

http://journal.aesonnigeria.org

http://www.ajol.info/index.php/jae

Email: editorinchief@aesonnigeria.org

statements that oil palm fruit PHAs are meant for the jobless $(\bar{x}=3.43)$ and are meant for female gender $(\bar{x}=3.32)$. Figure 1 shows that the majority $(63.3 \%)$ of the respondents had favourable perception towards involvement in oil palm fruits PHAs while $31.7 \%$ indicated unfavourable perception. The fact that the majority exhibited favourable perception implies that a great potential for entrepreneurial development lies ahead of these activities.

Table 2: Perception of the respondents towards involvement in oil palm fruits PHAs

\begin{tabular}{lc}
\hline Perception statements & $\begin{array}{c}\text { Ranked mean }(\bar{x}) \\
(\mathrm{n}=120)\end{array}$ \\
\hline Means of generating income & $3.51^{\star}$ \\
Provides self-employment & $3.45^{\star}$ \\
For those that have no job & $3.43^{\star}$ \\
Meant for females & $3.32^{\star}$ \\
Are time consuming & $3.27^{\star}$ \\
Can generate raw materials for some industries & $3.27^{\star}$ \\
Can contribute to community development & $3.17^{\star}$ \\
Increase foreign exchange potentials of the oil & $3.14^{\star}$ \\
Involve the use of expensive modern equipment & 2.22 \\
Involve a lot of drudgery & 1.98 \\
\hline
\end{tabular}

${ }^{*} \geq 2.50$ (Cut-off point). Source: Field survey, 2017

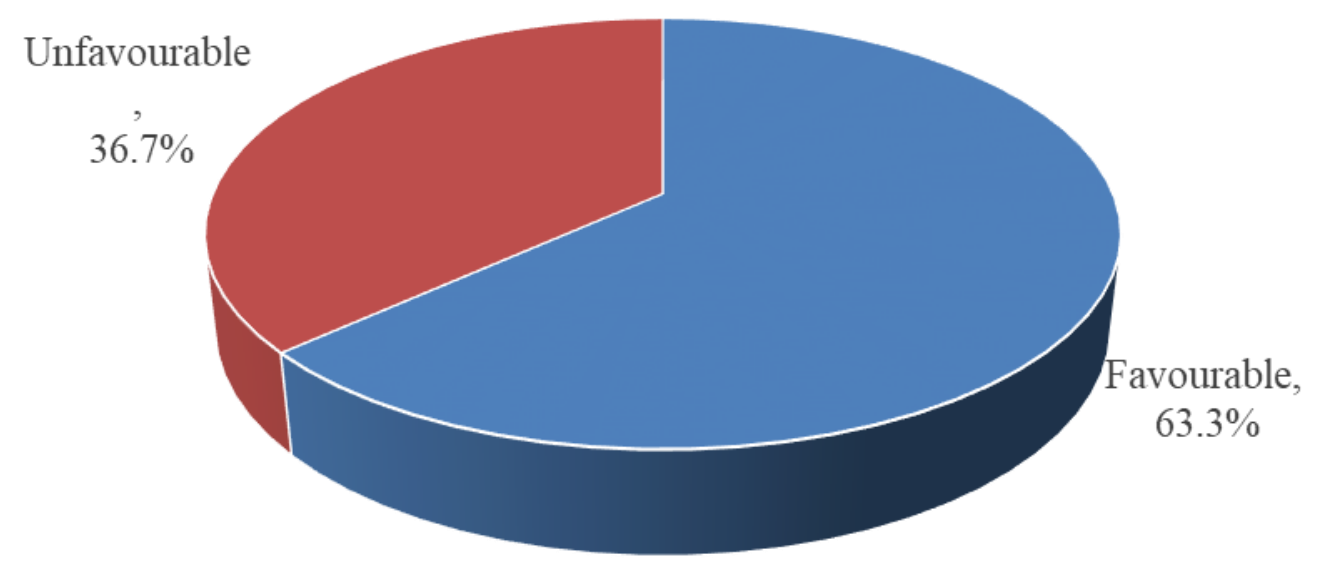

Figure 1: Perception of the respondents towards involvement in oil palm fruits PHAs

PHAs Activities of Respondents

Table 3 shows that respondents were involved in multiple PHAs with marketing activities $(86.8 \%)$ taking the lead. Followed by storage $(80 \%)$, packaging $(60.8 \%)$, gathering of loose 
Creative Commons User License: CC BY-NC-ND

Abstracted by: EBSCOhost, Electronic Journals Service (EJS),

Google Scholar, Journal Seek, Scientific Commons,

Food and Agricultural Organization (FAO), CABI and Scopus

http://eoi.citefactor.org/10.11226/v23i4
Journal of Agricultural Extension

Vol. 24 (1) January, 2020

ISSN(e): 24086851; ISSN(Print); 1119944X

http://journal.aesonnigeria.org

http://www.ajol.info/index.php/jae

Email: editorinchief@aesonnigeria.org

fruits $(56.5 \%)$, picking of fruits $(51.7 \%)$ and removal of debris $(50 \%)$. Others include digestion of boiled fruits $(47.5 \%)$, boiling of palm fruits $(44.5 \%)$, gathering of bunches (42.5\%), boiling of palm fruits (42.5\%) and clarification of oil (40.8\%). These PHAs involved in by respondents are potential sources of employment and means of livelihood to rural households. The finding agrees with Ohimain, et al. (2012) and Ohimain, et al. (2014) that oil palm sector provide employment opportunities for rural dwellers in Nigeria.

\begin{tabular}{lc} 
Table 3: Types of oil palm fruits PHAs involved in by respondents \\
\hline *PHAs & $\begin{array}{l}\text { Percentages } \\
\text { ( } \mathbf{n = 1 2 0 )}\end{array}$ \\
\hline Marketing & 85.8 \\
Storage & 80.0 \\
Packaging & 60.8 \\
Gathering of loose fruits & 56.5 \\
Picking of fruits & 51.7 \\
Removal of debris & 50.0 \\
Covering of chopped bunches & 47.5 \\
Digestion of boiled oil & 44.5 \\
Gathering of bunches & 42.5 \\
Boiling of palm fruit & 42.5 \\
Clarification of oil & 40.8 \\
Extraction of oil & 39.2 \\
Chopping of bunches & 35.3 \\
Harvesting of palm bunches & 31.7 \\
\hline
\end{tabular}

Source: Field survey, $2017 \quad{ }^{*}$ Multiple responses

Respondents' Involvement in Oil Palm Fruit PHAs

This was measured using nature, form and frequency of involvement.

Nature of Involvement

Results in Table 4 show that more than half $(55.8 \%)$ of the respondents were involved in oil palm fruits PHAs on a full-time basis while $44.2 \%$ engaged in it on part-time implying that the activities were providing employment for a significant proportion of rural households in the study area.

\section{Form of Involvement}

Table 4 shows further that $43.3 \%$ of the respondents were self-employed in these activities, $29.2 \%$ were employers of labour while 27.5 percent were employed labourers. The fact that oil palm fruits PHAs were not only providing employment opportunities for the owners alone, but also serve as a means of employing others who could have been jobless, implies that these activities have entrepreneurial capabilities that could enhance the socioeconomic status of rural households if well exploited. 
Creative Commons User License: CC BY-NC-ND

Abstracted by: EBSCOhost, Electronic Journals Service (EJS),

Google Scholar, Journal Seek, Scientific Commons,

Food and Agricultural Organization (FAO), CABI and Scopus

http://eoi.citefactor.org/10.11226/v23i4
Journal of Agricultural Extension

Vol. 24 (1) January, 2020

ISSN(e): 24086851; ISSN(Print); $1119944 X$

http://journal.aesonnigeria.org

http://www.ajol.info/index.php/jae

Email: editorinchief@aesonnigeria.org

Table 4: The nature and form of involvement in palm oil PHAs

\begin{tabular}{ll}
\hline Variables & Percentage $(\mathbf{n}=\mathbf{1 2 0})$ \\
\hline Nature of involvement & \\
Part time & 44.2 \\
Full time & 55.8 \\
Form of involvement & \\
Employed labourer & 27.5 \\
Self employed & 43.3 \\
Employer & 29.2 \\
\hline
\end{tabular}

Source: Field survey, 2017

Frequency of Involvement

Results in Table 5 show that with the cut-off point of 1.50 , respondents were actively involved in oil palm fruits PHAs such as marketing $(\bar{x}=2.62)$, storage $(\bar{x}=2.59)$, packaging $(\bar{x}=2.24)$, boiling of palm fruits $(\bar{x}=1.93)$, extraction of crude oil $(\bar{x}=1.89)$, gathering of bunches $(\bar{x}=1.88)$, removal of debris $(\bar{x}=1.81)$, clarification of oil $(\bar{x}=1.76)$, covering of chopped bunches $(\bar{x}=1.73)$, digestion of boiled fruits $(\bar{x}=1.71)$, picking of fruits $(\bar{x}=1.71)$ and chopping of bunches ( $\bar{x}=1.56)$ while they were least involved in harvesting $(\bar{x}=1.24)$. The active involvement of respondents observed in almost all the PHAs could be an indication that they were smallholder operators using manual labour for the majority of the activities. The finding is in agreement with Osei-Amponsah et al. (2018) assertion that majority of oil palm activities are done manually. The least involvement of respondents in harvesting could also be an indication of the high risk involved and an implication that this activity requires some level of expertise and improved technology.

Table 5: The frequency of involvement in oil palm fruit PHAs

\begin{tabular}{lc}
\hline Activities & Ranked mean $(\bar{x})(\mathrm{n}=120)$ \\
\hline Marketing & $2.62^{*}$ \\
Storage & $2.59^{*}$ \\
Packaging & $2.24^{*}$ \\
Boiling of palm fruits & $1.93^{*}$ \\
Gathering of loose fruits & $1.90^{*}$ \\
Extraction of crude oil & $1.89^{*}$ \\
Gathering of bunches & $1.88^{*}$ \\
Removal of debris & $1.81^{*}$ \\
Clarification of oil & $1.76^{*}$ \\
Covering of chopped bunches & $1.73^{*}$ \\
Digestion of boiled fruits & $1.71^{*}$ \\
Picking of fruits & $1.71^{*}$ \\
Chopping of bunches & $1.56^{*}$ \\
Harvesting of palm bunches & 1.24 \\
\hline
\end{tabular}

Grand mean $=1.90$

${ }^{*} \geq 1.50$ (Cut-off point) 
Creative Commons User License: CC BY-NC-ND

Abstracted by: EBSCOhost, Electronic Journals Service (EJS),

Google Scholar, Journal Seek, Scientific Commons,

Food and Agricultural Organization (FAO), CABI and Scopus

http://eoi.citefactor.org/10.11226/v23i4
Journal of Agricultural Extension

Vol. 24 (1) January, 2020

ISSN(e): 24086851; ISSN(Print); $1119944 X$

http://journal.aesonnigeria.org

http://www.ajol.info/index.php/jae

Email: editorinchief@aesonnigeria.org

\section{Level of Respondents' Involvement in Oil Palm Fruit PHAs}

Composite involvement scores of respondents from the three indicators were categorised into high, moderate and low levels using mean and standard deviation. Figure 2 shows that $19.2 \%$ of the respondents were highly involved in oil palm fruits PHAs, almost two-third (61.7\%) were moderately involved while $19.2 \%$ had low level of involvement. The fact that minority of the respondents had low involvement in oil palm fruit PHAs could be an indication that these activities contribute significantly to the livelihood of rural households in the study area.

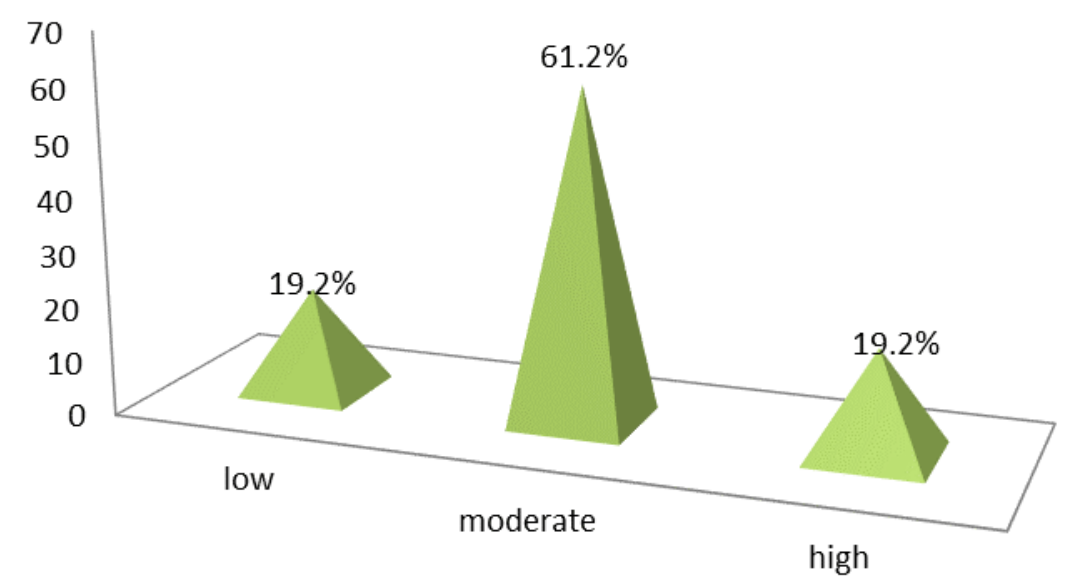

Figure 2: Levels of involvement in oil palm fruit PHAs

\section{Constraints to Involvement in Oil Palm Fruits PHAs}

Results in Table 6 show that lack of modern processing unit $(\bar{x}=2.96)$ took the lead among the constraints limiting respondents' involvement in oil palm fruits PHAs, closely followed by inadequate credit facilities ( $\bar{x}=2.90)$, lack of adequate technology $(\bar{x}=2.81)$, high cost of transportation ( $\bar{x}=2.80)$, low level of education $(\bar{x}=2.80)$, unavailability of required technology $(\bar{x}=2.78)$, high cost of labour $(\bar{x}=2.74)$ and unstable price of oil palm products $(\bar{x}=2.58)$. The findings imply that relevant rural development agencies should give priority focus to minimizing these problems to enhance sustainable interest of both the present and potential entrepreneurs along oil palm value chain development. The findings agree with Chukwu and Nwaiwu (2012) who established that lack of funds, poor processing facilities and transportation problems constitute the major challenges facing oil palm industry in Nigeria. 
Creative Commons User License: CC BY-NC-ND

Abstracted by: EBSCOhost, Electronic Journals Service (EJS),

Google Scholar, Journal Seek, Scientific Commons,

Food and Agricultural Organization (FAO), CABI and Scopus

http://eoi.citefactor.org/10.11226/v23i4
Journal of Agricultural Extension

Vol. 24 (1) January, 2020

ISSN(e): 24086851; ISSN(Print); $1119944 X$

http://journal.aesonnigeria.org

http://www.ajol.info/index.php/jae

Email: editorinchief@aesonnigeria.org

Table 6. Constraints limiting respondents' involvement in oil palm fruits PHAs

Constraints Ranked mean

$(\bar{x})(\mathrm{n}=120)$

\begin{tabular}{ll}
\hline Lack of modern processing facilities & $2.96^{*}$ \\
Inadequate access to credit facilities & $2.90^{*}$ \\
Lack of adequate technology & $2.81^{*}$ \\
High cost of transportation & $2.80^{*}$ \\
Low level of education & $2.80^{*}$ \\
Unavailability of required technology & $2.78^{*}$ \\
High cost of labour & $2.74^{*}$ \\
Unstable price of palm oil products & $2.58^{*}$ \\
Continuous dependence on manual processing by local & 2.43 \\
producers & \\
High risk in processing and marketing & 2.22 \\
Unavailability of markets & 2.19 \\
Lack of storage amenities & 1.98 \\
Poor transport amenities & 1.90 \\
\hline
\end{tabular}

${ }^{\star} \geq 2.50$ (Cut-off point). Source: Field survey, 2017

\section{Relationship between Involvement in Oil Palm Fruits PHAs and Personal and Socio-economic Characteristics of Respondents}

Table 7 shows that, of all the personal and socio-economic variables measured on nominal scale, only sex $(\chi 2=28.601 ; \mathrm{p} \leq 0.01)$ had significant association with involvement in oil palm fruits PHAs implying that sex is a determinant of involvement. The finding is in line with Ohimain, Emeti, Izah and Eretinghe (2014) who reported that male dominated the oil palm sector in their study area. On the other hand, results of correlation analysis in Table 8 show that years of schooling $(r=0.322 ; p \leq 0.01)$ and family size $(r=0.210$; had positive and significant relationship with the respondents' involvement in oil palm fruits PHAs. This implies that the higher the years of schooling of the respondents, the higher their involvement in oil palm fruits PHAs and vice-versa. Also, the larger the family sizes of the respondents, the higher their involvement in oil palm fruit PHAs.

Table 7: Association between selected personal characteristics and level of involvement

\begin{tabular}{lll}
\hline Personal characteristics & Chi-square & Degree of freedom \\
\hline Sex & $28.601^{* *}$ & 2 \\
Marital status & 5.839 & 6 \\
Religion & 0.931 & 4 \\
Ethnicity & 2.830 & 4 \\
Primary occupation & 2.696 & 6 \\
\hline${ }^{* \star}$ &
\end{tabular}


Creative Commons User License: CC BY-NC-ND

Abstracted by: EBSCOhost, Electronic Journals Service (EJS),

Google Scholar, Journal Seek, Scientific Commons,

Food and Agricultural Organization (FAO), CABI and Scopus

http://eoi.citefactor.org/10.11226/v23i4
Journal of Agricultural Extension

Vol. 24 (1) January, 2020

ISSN(e): 24086851; ISSN(Print); 1119944X

http://journal.aesonnigeria.org

http://www.ajol.info/index.php/jae

Email: editorinchief@aesonnigeria.org

Table 8: Relationship between selected personal characteristics of respondents and involvement in oil palm fruits PHAs

\begin{tabular}{ll}
\hline Variables & $\begin{array}{l}\text { Correlation } \\
\text { coefficient(r) }\end{array}$ \\
\hline Age & -0.059 \\
Family size & $0.210^{* *}$ \\
Years of residency & -0.149 \\
Years of schooling & $0.322^{* *}$ \\
Total income from palm oil & 0.033 \\
\hline${ }^{* *} P \leq 0.01$. Source: Field survey, 2017
\end{tabular}

Conclusion and Recommendation

The majority of the processors were moderately involved in oil palm fruits PHAs and many also indicated favourable perceptions towards involvement in these activities. However, lack of modern processing centres, inadequate access to credits and lack of adequate processing technologies were the major constraints to these activities in the study area.

To enhance rural households' involvement in oil palm fruit PHAs, relevant stakeholders such as national Centre for Agricultural Mechanization should develop appropriate and affordable processing facilities while the government also provides functional credit facilities through micro finance institutions loan scheme with low interest rate. Households in oil palm fruit PHAs can also form themselves into viable cooperative societies and pool their resources together to solve the problem of lack of capital.

\section{References}

Adeniyi, O. R., Ogunsola, G. O. and Olawusi, D. (2014). Methods of Oil Palm Processing in Ogun State, Nigeria. A Resource Use Efficiency Assessment. American International Journal of Contemporary Research 4(8):173-179

Agriculture Nigeria (2019). Available online at https://www.agriculturenigeria.com/production/crop-production/general-crops/oil-palm/

Akangbe, J. A., Adesiji, G. B., Fakayode, S. B. and Aderibigbe, Y. O. (2011). Towards Palm Oil Self-sufficiency in Nigeria: Constraints and Training needs Nexus of Palm Oil Extractors. J. Hum. Ecol. 33(2): 139-145.

Barcelos E, de Almeida Rios S, Cunha RNV, Lopes R, Motoike SY, Babiychuk E, Aleksandra S.and Kushnir S. (2015). Oil palm natural diversity and the potential for yield improvement. Frontiers in Plant Science (6):190. 
Creative Commons User License: CC BY-NC-ND

Abstracted by: EBSCOhost, Electronic Journals Service (EJS),

Google Scholar, Journal Seek, Scientific Commons,

Food and Agricultural Organization (FAO), CABI and Scopus

http://eoi.citefactor.org/10.11226/v23i4
Journal of Agricultural Extension

Vol. 24 (1) January, 2020

ISSN(e): 24086851; ISSN(Print); 1119944X

http://journal.aesonnigeria.org

http://www.ajol.info/index.php/jae

Email: editorinchief@aesonnigeria.org

Business Innovation Growth (BIG). (2017). Palm Oil Industry. Available online at https://bigportal.org.ng/bigwebsite/palmoilindustry

Chukwu, A. O. and Nwaiwu, J. C., (2012). Evaluation of gender participation in palm oil processing in Ohaji Egbema Local Government Area of Imo State. Int'l Journal of Agric. and Rural Dev.,15(2), 972 - 975

Conway, J. (2018). Nigeria's palm oil consumption 2011/12-2018/2019. Available online at https://www.statista.com/statistics/489451/palm-oil-consumption-nigeria/

Ekenta, C.M., Ajala, M.K., Akinola, M.O. and Oseni, Y. (2017). Abandoned Nigerian economic resources: The case of oil palm. Int. J. Agric. Ext. Rural Dev. Studies, 4 (2), 1-16

Embrandiri, A., Singh, R.P., Ibrahim, H. M. and Ramli, A.A. (2011). Land application of biomass residue generated from palm oil processing: its potential benefits and threats. Springer Science. Environmentalist, DOI 10.1007/s 10669-011-9367-0.

Ibitoye, O.O., Akinsorotan, A.O., Meludu, N.T. and Ibitoye, B.O. (2011). Factors affecting oil palm production in Ondo State of Nigeria. Journal of Agriculture and Social Research. 11(2), Pp. $97-105$

Izah, S. C., Ohimain, E. I., and Angaye, T. C. N. (2016). Potential thermal energy from palm oil processing solid wastes in Nigeria: mills consumption and surplus quantification. British Journal of Renewable Energy, vol. 1, pp. 38-44

Nyakuma, B. B., 2015. "Bioelectricity potential of oil palm waste in Malaysia." In 3rd International Conference. Research and Education in Natural Sciences. Shkodra, Albania

Ohimain, E. I., Emeti, C. I., Sylvester, C., Izah, S. C., and Eretinghe, D. A. (2014). Small-scale palm oil processing business in Nigeria; A feasibility study. Greener Journal of Business and Management Studies, 4(3),70-82

Ohimain, E. I., Emeti, C. I. and Izah, S. C. (2014). Employment and Socioeconomic Effects of Semi mechanized Palm Oil Mill in Bayelsa State, Nigeria. Asian Journal of Agricultural Extension and Sociology, vol. 3, pp. 206-216.

Ohimain, E. I. and Izah, S. C. (2014). Energy self-sufficiency of smallholder oil palm processing in Nigeria. Renewable Energy, vol. 63, pp. 426-431

Ohimain, E. I., Daokoru-Olukole, C., Izah, S. C., and Alaka, E. E. (2012). Assessment of the quality of crude palm oil produced by smallholder processors in Rivers State, Nigeria. Nigerian Journal of Agriculture, Food and Environment, vol. 8, pp. 28-34. 
Creative Commons User License: CC BY-NC-ND

Abstracted by: EBSCOhost, Electronic Journals Service (EJS),

Google Scholar, Journal Seek, Scientific Commons,

Food and Agricultural Organization (FAO), CABI and Scopus

http://eoi.citefactor.org/10.11226/v23i4
Journal of Agricultural Extension

Vol. 24 (1) January, 2020

ISSN(e): 24086851; ISSN(Print); 1119944X

http://journal.aesonnigeria.org

http://www.ajol.info/index.php/jae

Email: editorinchief@aesonnigeria.org

Ohimain, E. I., Oyedeji, A. A., and Izah, S. C. (2012). Employment effects of smallholder oil palm processing plants in Elele, Rivers State, Nigeria. International Journal of Applied Research and Technology, vol. 1, pp. 83-93

Ohimain, E. I. and Izah, S. C. (2014). Contribution of manual energy to palm oil processing by smallholders in Nigeria. Sky Journal of Agricultural Research, vol. 3, pp. 137-141

Ohimain, E. I. and Izah, S. C. (2013). Gaseous emissions from a semi-mechanized oil palm processing mill in Bayelsa state, Nigeria. Continental Journal of Water, Air and Soil Pollution, vol. 4, pp. 171-181

Ohimain, E. I., Izah, S. C., and Obieze, F. A. U. (2013). Material-mass balance of smallholder oil palm processing in the Niger Delta, Nigeria." Advance Journal of Food Science and Technology, vol. 5, pp. 289- 294

Onwumwere, J., Onwusiribe, N. and Iheanatu, C. (2014). Value chain analysis of palm fruit production and processing in Abia State, Nigeria. Asian Journal of Agricultural Extension, Economics \& Sociology, 3(3), 243-256

Onoh, P. A .and Peter-Onoh .C .A. (2012). Adoption of improved oil palm production technology among farmers in Aboh Mbaise local government area of Imo State. International Journal of Agriculture and Rural Development. 15 (2), Pp. 966 - 971

Osei-Amponsah, C., Agbotse, P., Swanzy, F. and Stomph, T. J. (2018). Role of smallscale enterprises in Agricultural Development Agendas: Insights from oil palm processing enterprises in the Kwaebibirem district of Ghana. Ghana Journal of Agric. Sci., vol.52, 131-144

Partnership Initiatives in The Niger Delta (PIND) Foundation. (2019). Palm oil value chain project. Available online at https://pindfoundation.org/project/palm-oilvalue-chain-project/ 